\title{
HASIL BELAJAR SISWA PADA PEMBELAJARAN BIOLOGI KONSEP SISTEM REPRODUKSI WANITA MELALUI PENERAPAN PENDEKATAN EKSPOSITORI
}

\author{
Ukit, Iwan Ridwan Yusup, Ike Swastini Dewi \\ Program Studi Pendidikan Biologi \\ Universitas Islam negeri Sunan Gunung Djati Bandung
}

\begin{abstract}
Abstrak
Hasil belajar siswa pada mata pelajaran biologi di SMAN 24 Kota Bandung senantiasa dilakuakn upaya peningkatan kualitas hasil pembelajaran.Hal tersebut dilihat dari nilai ulangan harian, seperti pada konsep system reproduksi pada wanita.Tujuan penelitian ini adalah untuk mengetahui hasil belajar siswa baik kognitif, afektif dan psikomotor siswa serta peningkatan hasil belajar mereka setelah pembelajaran berlangsung dengan menggunakan pendekatan ekspositorisub materi pokok sistem reproduksi wanita. Metode yang digunakan adalah Penelitian Tindakan Kelas (PTK) bentuk kolaboratif parsipatoris.Hasil penelitian terhadap hasil belajar siswa dengan menggunakan pendekatan ekspositori pada sub materi pokok sistem reproduksi wanita diperoleh data yaitu (1) Hasil belajar kognitif siswa berdasarkan pretes dengan nilai 31.9, sedangkan hasil belajar postes dengan nilai 59.6. Hal tersebut menunjukkan bahwa terdapat peningkatan hasil belajar secara signifikan karena $t_{\text {hitung }}=-10.392<t_{\text {daftar }}=2.656$, dengan rata-rata nilai gain sebesar 28. (2) Sikap siswa setelah proses pembelajaran berlangsung menyatakan bahwa sebagian besar siswa $(52.12 \%)$ setelah proses pembelajaran menunjukkan sikap senang terhadap pendekatan ekspositori,35.88\% siswa kurang menyukai terhadap pendekatan ekspositori dan $12.00 \%$ siswa tidak menyatakan sikap (ragu) terhadap pendekatanekspositori setelah pembelajaran berlangsung. (3) Keterampilan siswa berkembang ke arah positif, terlihat dari rata-rata keterampilan siswa siklus I sebesar $61.0 \%$, siklus II sebesar $80.0 \%$ dan keterampilan siswa pada siklus III sebesar 91.5\%, (4) Hasil belajar siswa dari ketiga aspek terlihat adanya peningkatan hasil belajar demikian pula dengan sikap dan keterampilan mereka berkembang kearah positif, hal tersebut didukung dari hasil observasi dan wawancara siswa selama proses pembelajaran.
\end{abstract}

Kata Kunci: Pendekatan Ekspositori, Hasil belajar, Sistem Reproduksi, PTK.

\section{Pendahuluan}

Guru berfungsi sebagai perancang pengajar, pengelola pengajaran dan penulis prestasi belajar siswa. Dari hal tersebut terlihat fungsi seorang guru dengan harapan untuk pandai mengarahkan kegiatan belajar siswa agar mencapai keberhasilan dalam belajar sebagai mana yang ditetapkan dalam proses belajar mengajar (PBM).

Pelaksanaan PBM menuntut guru memerlukan metode dan pendekatan supaya pencapaian keberhasilan dalam belajar lebih maksimal. Metode dan pendekatan tepat disesuaikan dengan konsep yang akan diajarkan kepada siswa. Metode mengajar adalah suatu cara menyajikan suatu materi pelajaran. Sedangkan pendekatan adalah cara yang digunakan untuk mencapai tujuan dalam hal ini pengetahuan ilmiah (Abu Ahmadi dalam Rahayu Dindardiya, 2007: 3).

Muhibbin Syah (2004: 173) menyatakan bahwa hasil belajar dipengaruhi oleh dua faktor yaitu faktor intern dan faktor ekstern. Faktor intern siswa meliputi gangguan dan kekurangmampuan psiko-fisik yang bersifak 
kognitif, afektif dan psikomotor. Sedagkan faktor ekstern meliputi semua situasi dan kondisi lingkungan sektar yang tidak mendukung aktivitas belajar siswa yaitu diantaranya lingkungan keluarga, lingkungan sekitar dan lingkunagan sekolah.

Penggunaan metode dan pendekatan yang tepat dapat meningkatkan kemampuan kognitf, afektif dan psikomotor siswa. Melalui pendekatan ekspositori diharapkan siswa mampu memahami materi yang disampaikan dalam proses belajar mengajar.

Menurut keterangan guru biologi kelas XI SMA 24 Kota Bandung, bahwa hasil belajar mereka masih kurang berdasarkan studi pendahuluan, hal tersebut terlihat dalam nilai ulangan harian mereka pada dua sub materi pokok terakhir. Oleh karena itu supaya terjadinya peningkatan hasil belajar siswa perlu dilakukan proses pembelajaran dengan menggunakan pendekatan pembelajaran yang tepat. Berdasarkan hasil belajar tersebut mendorong agar pembelajaran berikutnya perlu diadakannya perbaikan sehingga adanya peningkatan hasil belajar siswa. Penelitian Tindakan Kelas (PTK) menerapkan suatu bentuk penelitian yang bersifat reflektif sehingga mendorong untuk dilakukannya perbaikan, dengan tindakan perbaikan dan didukung melalui suatu pendekatan tepat diharapkan dapat mendukung dalam upaya peningkatan hasil belajar siswa sub materi pokok sistem reproduksi wanita.

Sub materi pokok sistem reproduksi wanita lebih tepat untuk dikaji secara terperinci pada jenjang pendidikan SMA, melalui pendekatan ekspositori menempatkan guru sebagai pusat pengajaran, karena guru lebih aktif memberikan informasi, menerangkan suatu konsep, mendemontrasikan keterampilan dalam memperoleh pola, aturan, dalil, memberi soal beserta penyelesaiannya, memberikan kesempatan kepada siswa untuk bertanya. Pendekatan ini dapat memberikan hasil yang lebih lama diingat, mudah ditransfer dan dapat meningkatkan motivasi yang intrinsik (Tabrani Rusyan, 1989: 178).

\section{Metode Penelitian}

\section{a. Desain Penelitian}

Metode yang digunakan dalam penelitian ini adalah Metode Penelitian Tindakan Kelas (PTK). Menurut Rochiati Wiraatmadja (2007:12) yang dimaksud dengan Penelitian Tindakan Kelas (PTK) adalah suatu bentuk penelitian yang bersifat reflektif dengan melakukan tindakan tertentu agar dapat memperbaiki dan atau meningkatkan praktek-praktek pembelajaran dikelas secara lebih profesional.

Pada umumnya pelaksanaan Penelitian Tindakan Kelas (PTK) bersifat spiral. Menurut Mc Tagart (1998) model ini terdiri dari empat komponen yaitu (1) rencana; (2) tindakan; (3) observasi; (4) refleksi (Zainal Aqib, 2007:30).

Penelitian Tindakan Kelas (PTK) bersifat siklus dan spiral artinya semakin lama semakin meningkat perubahan dan pencapaian hasilnya. Proses siklus mencapai kemantapan jika guru dan peneliti merasa puas terhadap apa yang diperolehnya. Tetapi dalam penelitian ini, peneliti membatasi penelitian menjadi tiga siklus. Dalam setiap siklus, setelah pembelajaran dilakukan refleksi untuk mengetahui kelemahan dan kelebihan dari apa yang telah dilakukan. Kemudian menyusun perbaikan sejalan dengan hasil refleksi untuk digunakan pada siklus berikutnya. Untuk lebih jelasnya bagan siklus Penelitian Tindakan Kelas (PTK) berikut ini: 


\section{Alur Penelitian Tindakan Kelas (Diadaptasi dari Eliot, Hopkins 1993)}

\section{Orientasi dan Observasi Lapangan \\ Identifikasi Masalah \\ Observasi awal pembelajaran biologi \\ Perencanaan keseluruhan siklus I, II dan III}

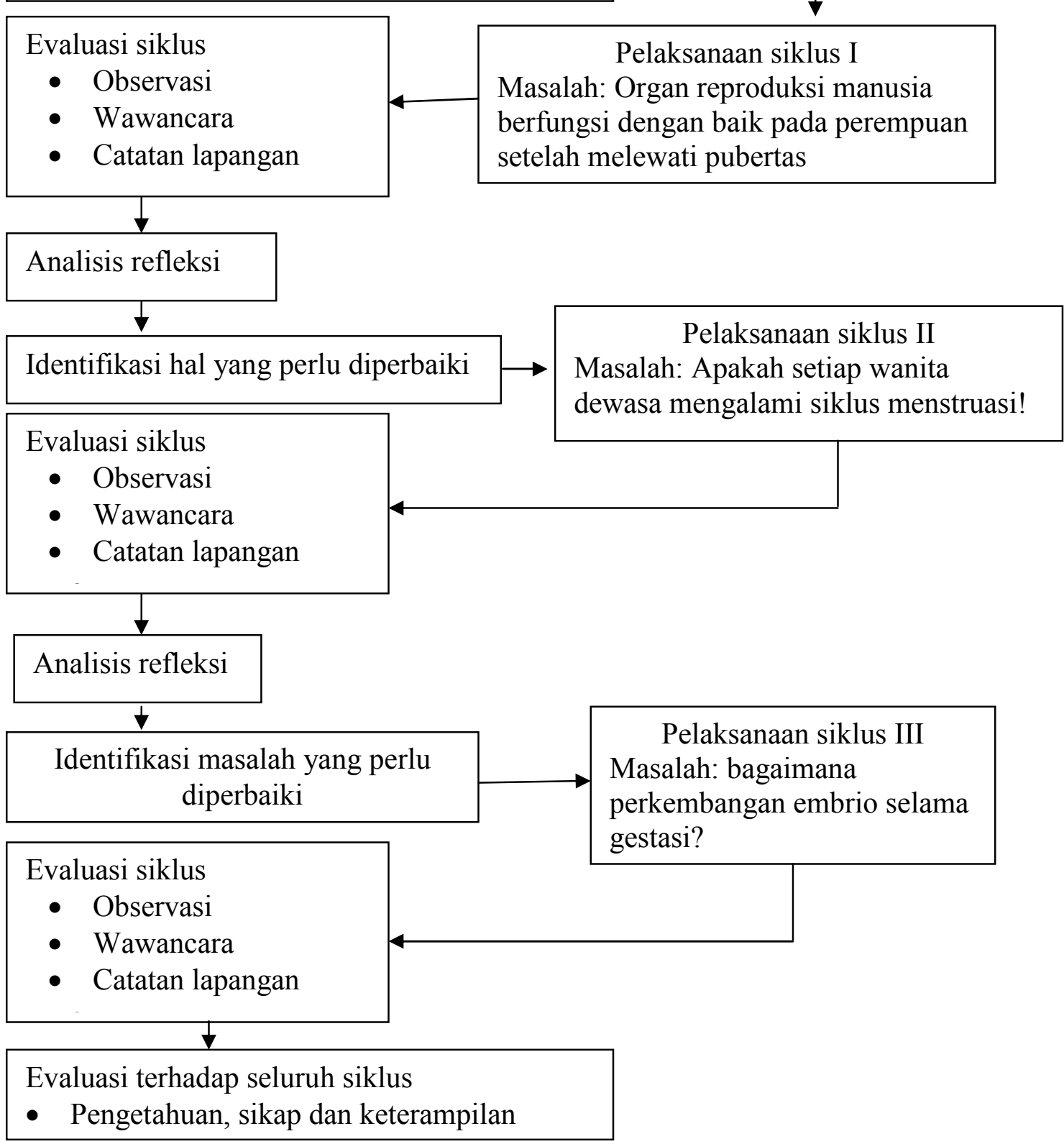

Gambar 1. Skema Alur Penelitian PTK 


\section{b. Subjek Penelitian}

Lokasi penelitian yang diambil adalah SMAN 24 Kota Bandung, adapun alas an yang menjadi pertimbangan adalah lokasi ini merupakan tempat dimana guru mitra mengajar, sehingga pelaksanaan PTK sangat menunjang pada perbaikan dan pengembangan hasil belajar biologi. adapun subjek yang dijasikan penelitian adalah kelas XI-1 IPA. dengan jumlah siswa 34 orang.

\section{c. Instrumen Penelitian}

instrument penelitian ini meliputi (1) tes, bentuk tes ini merupakan tes objektif. dengan jumlah option lima $(\mathrm{A}, \mathrm{B}, \mathrm{C}, \mathrm{D}, \mathrm{E})$. dalam penelitian tindakan kelas ini tes mengacu pada ranah kognitif, siswa. (2) Lembar observasi, digunakan untuk mengetahui proses dan respon siswa selama proses pembelajaran dilaksanakan. (3) LKS merupakan pertanyaan yang digunakan untuk mengasah pengetahuan /konsep pada setiap pertemuan.

\section{Hasil dan Pembahasan}

Adapun analisis yang dilakukan meliputi hasil belajar siswa yaitu mengenai pengetahuan secara keseluruhan melalui tes awal (pretes) yang diperoleh sebelum pembelajaran dan tes akhir (postes) diperoleh sesudah pembelajaran pada sub materi pokok sistem reproduksi wanita dengan menggunakan pendekatan ekspositori, sikap dan keterampilan siswa terhadap pembelajaran dengan menggunakan pendekatan ekspositori. Adapun data observasi, wawancara, catatan lapangan dan refleksi setiap siklus digunakan untuk membantu dalam menginterpretasikan data hasil penelitian.

\section{a. Kognitif (Pengetahuan)}

Hasil belajar kognitif yaitu berupa penguasaan konsepsi siswa terhadap sub materi pokok sistem reproduksi wanita dengan menggunakan pendekatan ekspositori. Data yang diperoleh dari penilaian ini merupakan tes awal (pretes) yang diperoleh sebelum pembelajaran sub materi pokok sistem reproduksi wanita dan tes akhir (postes) yang diperoleh sesudah pembelajaran dengan menggunakan pendekatan ekspositori di salah satu sekolah suasta di .

Diagram Batang penguasaan konsep siswa sebagai berikut:

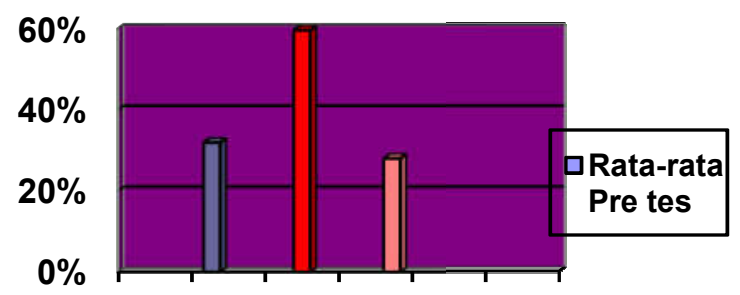

Gambar 2. Grafik Rata-rata Penguasaan Konsep

Gambar2. Menunjukan adanya peningkatan hasil belajar siswa yang tampak dari pencapaian pretes dan postes. Adanya peningkatan hasil belajar dalam pembelajaran pada sub materi pokok sistem reproduksi wanita dengan menggunakan pendekatan ekspositori.

(a) Uji Normalitas

Uji normalitas bertujuan untuk mengetahui apakah data pretes dan postes berdistribusi normal atau tidak. Adapun rumus yang digunakan adalah rumus Chi Kuadrat $\left(\mathrm{X}^{2}\right)$ dengan hasil perhitungan sebagai berikut:

Tabel 1Hasil Perhitungan UjiNormalitas

\begin{tabular}{ccccc}
\hline Nilai & $\mathbf{X}_{\text {hitung }}^{2}$ & $\mathbf{X}_{\text {daftar }}^{2}$ & Hasil & Interpretasi \\
\hline Pretes & 7.14 & 11.3 & $\begin{array}{c}\mathrm{X}_{\text {hitung }}^{2}< \\
\mathrm{X}_{\text {daftar }}^{2}\end{array}$ & $\begin{array}{c}\text { Berdistribusi } \\
\text { Normal }\end{array}$ \\
Postes & 1.83 & 11.3 & $\begin{array}{c}\mathrm{X}_{\text {hitung }}^{2} \\
\mathrm{X}_{\text {daftar }}^{2}\end{array}$ & $\begin{array}{c}\text { Berdistribusi } \\
\text { Normal }\end{array}$ \\
\hline
\end{tabular}

Tabel 1. menunjukan $\mathrm{X}_{\text {hitung }}^{2}<$

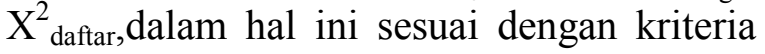
uji normalitas, maka dapat disimpulkan bahwa data pretes dan data postes berdistribusi normal. 
(b) Homogenitas

Setelah pengujian normalitas keduanya berdistribusi normal, maka dilakukan uji homogenitas dengan uji statistik F dengan perhitungan berikut:

Tabel 2. Hasil Perhitungan UjiHomogenitas

\begin{tabular}{cccc}
\hline $\mathbf{F}_{\text {hitung }}$ & $\mathbf{F}_{\text {daftar }}$ & Hasil & Interpretasi \\
\hline 1.93 & 2.31 & $\begin{array}{c}\mathrm{F}_{\text {hitung }}< \\
\mathrm{F}_{\text {daftar }}\end{array}$ & Homogen \\
\hline
\end{tabular}

Tabel 2. menunjukan $\mathrm{F}_{\text {hitung }}<$

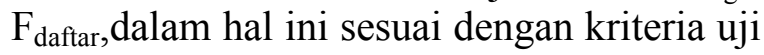
homogenitas, maka dapat disimpulkan bahwa data pretes dan data postes berdistribusi homogen.

(c) Pengujian Hipotesis

Uji hipotesis dilakukan untuk mengetahui ada tidaknya peningkatan hasil belajar siswa. Dari hasil uji $\mathrm{t}$ diperoleh $t_{\text {hitung }}=-10.392$ dengan taraf signifikan $0.01 \%$ dan derajat kebebasan sebesar 66 , maka diperoleh $t_{\text {daftar }}=2.656$. hal ini menunjukan $t_{\text {hitung }}$ berada diluar interval $\mathrm{t}_{\text {daftar }}<\mathrm{t}_{\text {hitung }}<\mathrm{t}_{\text {daftar }}$. Dengan demikian hipotesis alternatif $\left(\mathrm{H}_{1}\right)$ diterima yang berarti terdapat peningkatan hasil belajar siswa secara signifikan pada pembelajaran sistem reproduksi wanita dengan menggunakan pendekatan ekspositori.

\section{b. Afektif (Sikap)}

Data sikap siswa terhadap pembelajaranpada sub materi pokok sistem reproduksi wanitadiperoleh berdasarkan hasil angket. Untuk mengetahui bagaimana sikap siswa terhadap penerapan pendekatan ekspositori, disebarkan angket sebanyak 20 item kepada 34 responden dengan mengcu pada aspek yang telah ditentukan. Angket tersebut berbentuk pilihan ganda (multiple choice) yang terdiri dari 5 alternatif jawaban alternatif yaitu diantaranya Sangat Setuju (SS), Setuju (S), Ragu-ragu (R), Tidak Setuju (TS), dan Sangat Tidak Setuju (STS).

Tabel 3. Rekapitulasi Rata-rata Prsentase Sikap Siswa Per-aspek.

\begin{tabular}{lccccc}
\hline \multicolumn{1}{c}{ Aspek } & SS & S & R & TS & STS \\
\hline Pendekatan Ekspositori & $33,1 \%$ & $16,9 \%$ & $2,2 \%$ & $28,7 \%$ & $19,1 \%$ \\
Apersepsi & $18.4 \%$ & $30,1 \%$ & $19,1 \%$ & $20.6 \%$ & $11,8 \%$ \\
Eksplorasi & $23.5 \%$ & $25,0 \%$ & $13,1 \%$ & $29,6 \%$ & $8,8 \%$ \\
Aktivitas & $19,9 \%$ & $30,9 \%$ & $12,5 \%$ & $28,6 \%$ & $8,1 \%$ \\
Penugasan & $35.0 \%$ & $27.6 \%$ & $20.4 \%$ & $8.8 \%$ & $10.2 \%$ \\
Evaluasi & $22,0 \%$ & $27,2 \%$ & $5,2 \%$ & $25,0 \%$ & $20,6 \%$ \\
Rata-rata & $25.32 \%$ & $26.8 \%$ & $12.00 \%$ & $22.88 \%$ & $13.0 \%$ \\
\hline Jumlah & \multicolumn{2}{c}{$52.12 \%$} & $12.00 \%$ & \multicolumn{2}{c}{$35.88 \%$} \\
\hline
\end{tabular}

Dari tabel 3. mengenai sikap siswa dapat dilihat pernyataan rata-rata persentase siswa peraspek terhadap proses pembelajaran dengan menggunakan pendekatan ekspositori. Hasil penelitian menunjukan bahwa sebagian besar siswa $(52.12 \%)$ merasa senang dan antusias sekali belajar dengan menggunakan pendekatan ekspositori. Mereka merasa mudah mengerti belajar dengan menggunakan pendekatan ekspositori. Dari uraian data diatas dapat dibuat grafik batang skala sikap siswa terhadap proses pembelajaran pada sub materi pokok sistem reproduksi wanita dengan menggunakan pendekatan ekspositori.

Dari tabel 3.dapat disimpulkan bahwa sebagian besar siswa $(52.12 \%)$ merasa senang dengan pendekatan ekspositori, 35.88\% siswa kurang senang terhadap pendekatan ekspositori sedangkan $12.00 \%$ siswa ragu-ragu (tidak berperinsip) terhadap pendekatan ekspositori selama proses pembelajaran. 


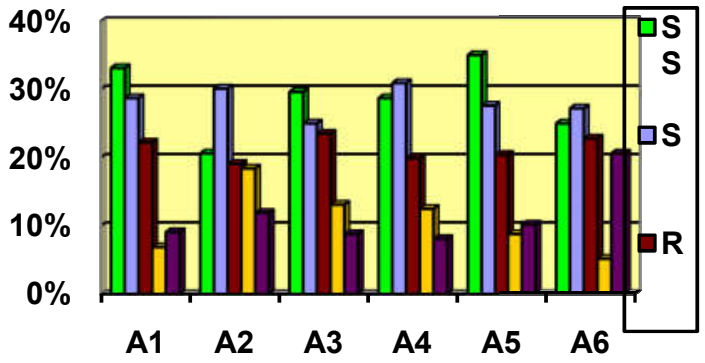

Gambar 3. Grafik Presentase Sikap Siswa Per-asapek.

Keterangan:

A1: Tanggapan siswa terhadap penggunaan pendekatan ekspositori

A2: Apersepsi

A3: Eksplorasi

A4: Aktivitas

A5: Penugasan

A6: Evaluasi

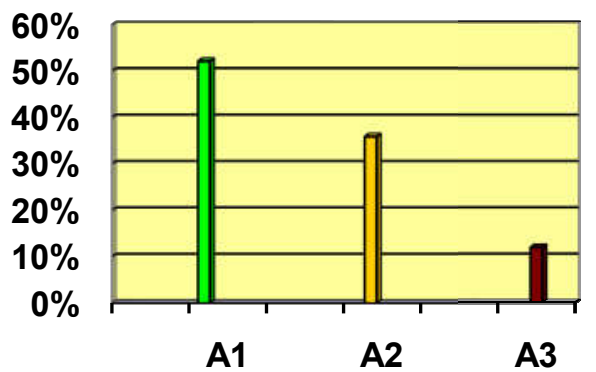

Keterangan:

A1: Sikap Siswa yang menerima terhadap pendekatan ekspositori

A2: Sikap Siswa yang menolak terhadap pendekatan ekspositori

A3: Tidak Berperinsip (ragu-ragu)

\section{c. Psikomotor (Keterampilan)}

Hasil penelitian diurutkan sesuai dengan proses pembelajaran siklus I, siklus II dan siklus III. Analisis proses pembelajaran siswa melakukan diskusi dan presentasi pada sub materi pokok sistem reproduksi wanita. Dari hasil pengamatan selama pembelajaran berlangsung diperoleh gambaran bahwa keterampilan siswa dapat dikembangkan. Keterampilan siswa yang diamati yaitu mengawali diskusi (K1), ikut berperan dalam diskusi (K2), mempresentasikan hasil diskusi (K3), menunjukan bagian pada slide (K4), mengajukan pernyataan (K5), menyimpulkan (K6).

Gambar 4. Grafik Presentase Sikap Siswa

Terhadap Pendekatan Ekspositori

Tabel 4. Keterampilan Siswa pada Siklus I (pertemuan ke-1)

\begin{tabular}{cccccccl}
\hline Kode Siswa & \multicolumn{7}{c}{ Keterampilan } \\
\hline & K1 & K2 & K3 & K4 & K5 & K6 & Kegiatan Siswa \\
A & $\checkmark$ & $\checkmark$ & $\checkmark$ & $\checkmark$ & $\checkmark$ & - & Mengenal organ reproduksi dengan \\
B & $\checkmark$ & $\checkmark$ & $\checkmark$ & $\checkmark$ & $\checkmark$ & - & fungsinya dan memahami proses \\
C & $\checkmark$ & $\checkmark$ & - & - & - & - & pembentukan gamet (Oogenesisi) \\
D & $\checkmark$ & $\checkmark$ & - & - & - & - & pada wanita (LKS 1) \\
E & $\checkmark$ & $\checkmark$ & $\checkmark$ & - & $\checkmark$ & - & \\
F & $\checkmark$ & $\checkmark$ & $\checkmark$ & - & $\checkmark$ & - & \\
\% & 100 & 100 & 66 & 33 & 66 & 0 & \\
\hline
\end{tabular}

\section{Keterangan:}

K1: Mengawali diskusi

K2: Ikut berperan dalam diskusi

K3: Mempresentasikan hasil diskusi

K4: Menjelaskan bagian-bagian pada media slide

K5: Mengajukan pertanyaan

K6: Menyimpulkan
Dari tabel 1.4diperoleh gambaran umum sebagai berikut: pada umumnya siswa telah mengembangkan keterampilan membuka diskusi, ikut berperan dalam diskusi, dan mempresentasikan hasil diskusi, tetapi ada beberapa siswa yang masih ragu 
dalam menjelaskan bagian pada slide dan mengajukan pertanyaan. Sedangkan untuk menyimpulkan semua siswa tidak sempat melakukannya karena waktu yang tidak memungkinkan.

Dari siswa yang diobservasi sebanyak enam orang, secara umum memperlihatkan keseriusan dalam diskusi dan mempresentasikan hasil diskusi, dua orang belum mampu dalam mempresentasikan hasil diskusi, empat orang belum piawai dalam menjelaskan bagian slide dan dua orang belum berani dalam mengajukan pertanyaan. Keterampilan siswa selama pembelajaran dalam siklus I terlihat adanya perkembangan keterampilan siswa pada pembelajaran siklus I sementara harus diperbaiki sehingga untuk pembelajaran berikutnya diharapkan adanya peningkatan.

Pada siklus I kegiatan pembelajaran terlihat masih kaku, siswa masih merasa kurang percaya diri, hal tersebut terlihat waktu mempresentasikan hasil diskusi dengan kelompok. Sebagian besar siswa hanya dapat menjelaskan yang terdapat pada slide yang telah disiapkan. Pertanyaan yang dilontarkan kepada temannya masih terlihat hati-hati, hal tersebut disebabkan karena sub bab yang dikaji bersifat individual, informasi ini diketahui dari pembicaraan siswa setelah pembelajaran berlangsung.

Setelah menganalisis hasil data observasi, wawancara dan beberapa catatan lapangan, siklus I, maka hipotesis siklus II dapat dirumuskan pada tabel 1.4 berikut:

Tabel 5. Refleksi Siklus I

\begin{tabular}{|c|c|c|c|c|}
\hline No & Kendala & Respon Siswa & $\begin{array}{c}\text { Catatan } \\
\text { Lapangan }\end{array}$ & Hipotesa Tindakan Siklus II \\
\hline 1. & $\begin{array}{l}\text { Lembar Diskusi } \\
\text { Siswa (LDS) agak } \\
\text { berbeda dengan } \\
\text { buku paket, } \\
\text { sehingga dalam } \\
\text { mencari } \\
\text { penjelasan siswa } \\
\text { merasa kesulitan }\end{array}$ & $\begin{array}{l}\text { Dengan adanya LDS } \\
\text { siswa kebingungan } \\
\text { maksud dari LDS } \\
\text { yang diberikan }\end{array}$ & $\begin{array}{l}\text { Gurur kurang mengangkat } \\
\text { topik materi yang akan } \\
\text { dipelajari sehingga saat } \\
\text { pembagian LDS ke } \\
\text { masing-masing kelompok } \\
\text { siswa kebingungan } \\
\text { (sebelum ada bimbingan ) }\end{array}$ & $\begin{array}{l}\text { Meningkatkan strategi } \\
\text { pengajaran dengan } \\
\text { Mengefektifkan pendekatan } \\
\text { ekspositori yaitu memberikan } \\
\text { waktu yang cukup selama } \\
\text { proses pembelajaran sehingga } \\
\text { materi yang telah dipelajari } \\
\text { dapat dipahami dengan baik. }\end{array}$ \\
\hline 2. & $\begin{array}{l}\text { Alokasi waktu } \\
\text { Belum sesuai }\end{array}$ & $\begin{array}{l}\text { Kurang puas dengan } \\
\text { proses pembelajaran } \\
\text { (waktu diskusi, } \\
\text { presentasi dan tanya } \\
\text { jawab) waktu yang } \\
\text { diberikan terlalu } \\
\text { sebentar }\end{array}$ & $\begin{array}{l}\text { Guru agak terburu-buru } \\
\text { selama pembelajaran } \\
\text { berlangsung, waktu yang } \\
\text { dijadwalkan takut tidak } \\
\text { sesuai }\end{array}$ & \\
\hline 3. & $\begin{array}{l}\text { Waktu yang } \\
\text { digunakan tiap } \\
\text { tahapan } \\
\text { pembelajaran } \\
\text { belum sesuai }\end{array}$ & $\begin{array}{l}\text { Pengisian LKS } \\
\text { kurang optimal } \\
\text { karena waktu yang } \\
\text { diberikan sebentar. }\end{array}$ & & \\
\hline
\end{tabular}

Berdasarkan kendala, catatan lapangan dan respon dari siswa pada siklus Idan analisis yang dikemukakan oleh peneliti dan observer, maka dilakukan perbaikan untuk proses pembelajaran siklus II. 
Tabel 6. Keterampilan Siswa pada Siklus II (pertemuan ke-2)

\begin{tabular}{cccccccc}
\hline \multirow{2}{*}{ Kode Siswa } & \multicolumn{9}{c}{ Keterampilan } & Kegiatan Siswa \\
\hline & K1 & K2 & K3 & K4 & K5 & K6 & \\
\hline A & - & $\checkmark$ & $\checkmark$ & $\checkmark$ & $\checkmark$ & $\checkmark$ & Memahami konsep siklus menstruasi \\
B & $\checkmark$ & $\checkmark$ & $\checkmark$ & $\checkmark$ & $\checkmark$ & $\checkmark$ & dan proses ovulasi (LKS 2) \\
C & $\checkmark$ & $\checkmark$ & $\checkmark$ & $\checkmark$ & - & $\checkmark$ & \\
D & $\checkmark$ & $\checkmark$ & $\checkmark$ & - & - & $\checkmark$ & \\
E & $\checkmark$ & $\checkmark$ & $\checkmark$ & - & $\checkmark$ & $\checkmark$ & \\
F & $\checkmark$ & $\checkmark$ & $\checkmark$ & $\checkmark$ & $\checkmark$ & $\checkmark$ & \\
$\%$ & 83 & 100 & 100 & 66 & 66 & 100 & \\
\hline
\end{tabular}

Pada tabel 5.diperoleh gambaran sebagai berikut: waktu membuka diskusi ada salah satu siswa yang belum siap, waktu diskusi berlangsung seluruh anggota kelompok terlarut dalam suasana diskusi, tetapi ada beberapa siswa saat menjelaskan gambar pada slide terlihat gugup dan beberapa siswa belum mampu mengajukan pertanyaan, sedangkan secara keseluruhan siswa sudah terampil dalam membuat kesimpulan setelah pembelajaran.

Pada umumnya siswa yang diteliti menunjukan adanya peningkatan keterampilan selama proses pembelajaran berlangsung. Siswa sudah mulai tampil berani dan terbuka dalam menyampaikan gagasannya, terbiasa dengan pembelajaran secara kelompok ditunjukan dengan seringnya komunikasi antar anggota kelompok sehingga pembelajaran yang terlihat kaku menjadi jalinan suatu proses pembelajaran yang kolaboratif baik siswa dengan siswa maupun siswa dengan guru.

Hasil analisis, observasi, wawancara dan catatan lapangan pada Siklus II, maka hipotesis tindakan untuk siklus III, dapat dirumuskan pada tabel 6

Tabel 7. Refleksi Siklus II

\begin{tabular}{|c|c|c|c|c|}
\hline No. & Kendala & Respon Siswa & $\begin{array}{c}\text { Catatan } \\
\text { Lapangan }\end{array}$ & $\begin{array}{c}\text { Hipotesa Tindakan Siklus } \\
\text { III }\end{array}$ \\
\hline 1. & & $\begin{array}{l}\text { Antusias dan Siap } \\
\text { dalam pembelajaran } \\
\text { yang akan } \\
\text { dilaksanakan }\end{array}$ & $\begin{array}{l}\text { Guru terlihat siap dalam } \\
\text { pelaksanaan pembelajaran dan } \\
\text { antisipatif terhadap siswa } \\
\text { yang mengalami kesulitan } \\
\text { selama proses pembelajaran }\end{array}$ & $\begin{array}{l}\text { Kesesuaian dengan } \\
\text { pendekatan yang } \\
\text { digunakan dalam } \\
\text { pembelajaran diharapkan } \\
\text { dapat mempermudah siswa } \\
\text { dalam memahami materi }\end{array}$ \\
\hline 2. & $\begin{array}{l}\text { Waktu masih } \\
\text { terlihat belum } \\
\text { sesuai dengan } \\
\text { tahapan } \\
\text { pembelajaran }\end{array}$ & & $\begin{array}{l}\text { Guru lebih terfokus dalam } \\
\text { membantu siswa yang } \\
\text { kesulitan dan membantu siswa } \\
\text { dalam memahami konsep } \\
\text { yang ada dalam LDS supaya } \\
\text { yang ditargetkan sesuai }\end{array}$ & yang telah dipelajari \\
\hline 3. & & $\begin{array}{l}\text { Siswa lebih cepat } \\
\text { memahami materi } \\
\text { dengan adanya } \\
\text { peranan guru sebagai } \\
\text { fasilitator }\end{array}$ & $\begin{array}{l}\text { Pelaksanaan pendekatan } \\
\text { ekspositori masih terasa } \\
\text { kurang optimal, konsep materi } \\
\text { yang dikuasai siswa masih } \\
\text { kurang }\end{array}$ & \\
\hline
\end{tabular}


Dengan adanya refleksi hasil diskusi antara peneliti dengan observer diharapkan pada siklus berikutnya pembelajaran menjadi lebih baik. Oleh karena itu melalui perbaikan pada hipotesa tindakan III diharapkan proses pembelajaran berkembang kearah yang lebih baik. Adanya tanggapan dari siswa melalui wawancara untuk pembelajaran berikutnya guru berusaha memotivasi siswa untuk belajar dan berperan serta selama pembelajaran berlangsung.

Tabel 8. Keterampilan Siswa pada Siklus III (pertemuan ke-3)

\begin{tabular}{cccccccl}
\hline Kode Siswa & \multicolumn{7}{c}{ Keterampilan } \\
\hline & K1 & K2 & K3 & K4 & K5 & K6 & Kegiatan Siswa \\
\hline A & $\checkmark$ & $\checkmark$ & $\checkmark$ & $\checkmark$ & $\checkmark$ & $\checkmark$ & Memahami proses fertilisasi, gestasi, \\
B & $\checkmark$ & $\checkmark$ & $\checkmark$ & $\checkmark$ & $\checkmark$ & $\checkmark$ & proses persalinan dan peranan ASI bagi \\
C & $\checkmark$ & $\checkmark$ & $\checkmark$ & $\checkmark$ & $\checkmark$ & $\checkmark$ & bayi dan ibu (LKS 3) \\
D & $\checkmark$ & $\checkmark$ & $\checkmark$ & $\checkmark$ & - & $\checkmark$ & \\
E & $\checkmark$ & $\checkmark$ & $\checkmark$ & - & $\checkmark$ & $\checkmark$ & \\
F & $\checkmark$ & $\checkmark$ & - & $\checkmark$ & $\checkmark$ & $\checkmark$ & \\
$\%$ & 100 & 100 & 83 & 83 & 83 & 100 & \\
\hline
\end{tabular}

Tabel 8 keterampilan siswa terlihat adanya peningkatan yang signifikan. Beberapa siswa belum bisa menyesuaikan sehingga saat presentasi, menunjukan bagian gambar pada slide dan mengajukan pertanyaan terlihat lebih berani tetapi masih hati-hati dan beberapa siswa memilih diam dan memperhatikan temannya.

Ketiga tabel diatas menggambarkan bahwa selama pembelajaran berlangsung dari siklus demi siklus keterampilan siswa berkembang kearah yang lebih baik. Dari uraian tersebut dapat dibuat grafik batang pengembangan keterampilan siswa terhadap pembelajaran biologi dengan menggunakan pendekatan ekspositori.

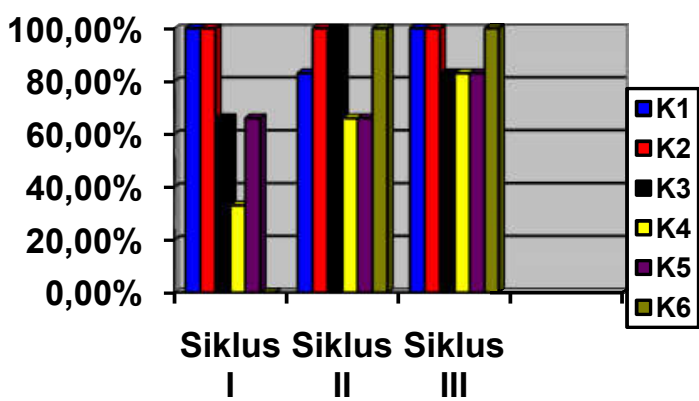

Gambar 5. Grafik Pengembangan Keterampilan Siswa

\section{Keterangan:}

K1: Mengawali diskusi

K2: Ikut berperan dalam diskusi

K3: Mempresentasikan hasil diskusi

K4: Menjelaskan bagian-bagian pada media slide

K5: Mengajukan pertanyaan

K6: Menyimpulkan

S1: Rata-rata pegembangan ketermpilan pada siklus I

S2: Rata-rata pegembangan ketermpilan pada siklus II

S3: Rata-rata pegembangan ketermpilan pada siklus III

Berkembangnya keterampilan siswa memungkinkan tumbuhnya pengetahuan dan sikap kearah positif selama pembelajaran yaitu diantaranya siswa mau dan mampu bekerja sama, menghargai pendapat orang lain dalam diskusi kelas, menjunjung tolerasi yang tinggi dengan memberikan penjelasan kepada temannya yang kurang (dalam pemahaman materi), mereka bahkan telah menunjukan sikap peduli terhadap kesehatannya setelah mengetahui setelah pembelajaran berlangsung. Hal ini terungkap dalam argumentasi siswa saat diskusi bahwa pemeliharaan organ reproduksi ternyata harus diperhatikan dan tidak boleh disepelekan. 
d. ObservasiKegiatan Siswa

Observasi atau pengamatan, yakni melihat langsung peristiwa, kejadian dan prilaku guru dan siswa pada saat kegiatan belajar mengajar berlangsung (Nana Sudjana, 1991:64). Kegiatan observasi dilakukan dengan tujuan untuk mengumpulkan informasi tentang situasi dan peristiwa proses pengajaran biologi dikelas. Hasil penelitian diperoleh dari observasi siswa selama pembelajaran, melalui kegiatan observasi prasiklus, siklus I, siklus II dan siklus III. Selama kegiatan pembelajaran berlangsung siswa menunjukan adanya perkembangan kearah yang baik, yaitu diantaranya siswa mulai berani dalam mengungkapkan pendapatnya kemudian mempresentasikannya. Secara tidak langsung dengan kegiatan tersebut siswa merasa termotivasi.

Tabel 9. Hasil Observasi Kegiatan Siswa Prasiklus

\begin{tabular}{ccccccccccc}
\hline & Kode & $10 ”$ & $10 ”$ & $10 ”$ & $10 ”$ & $10 ”$ & $10 ”$ & $10 ”$ & $10 ”$ & $10 ”$ \\
\hline No. & Siswa & 1 & 2 & 3 & 4 & 5 & 6 & 7 & 8 & 9 \\
\hline 1. & A & - & - & - & $\checkmark$ & $\checkmark$ & $\checkmark$ & $\checkmark$ & - & - \\
2. & B & $\checkmark$ & $\checkmark$ & $\checkmark$ & $\checkmark$ & - & - & - & - & - \\
3. & C & $\checkmark$ & - & - & - & $\checkmark$ & $\checkmark$ & $\checkmark$ & - & - \\
4. & D & - & $\checkmark$ & $\checkmark$ & $\checkmark$ & - & - & - & - & - \\
5. & E & $\checkmark$ & - & - & - & $\checkmark$ & $\checkmark$ & - & - & - \\
6. & F & - & $\checkmark$ & $\checkmark$ & $\checkmark$ & - & - & - & - & - \\
\hline
\end{tabular}

a. Aspek yang diamati

$1 \rightarrow \quad$ Mengamati Lembar Diskusi Siswa (LDS)

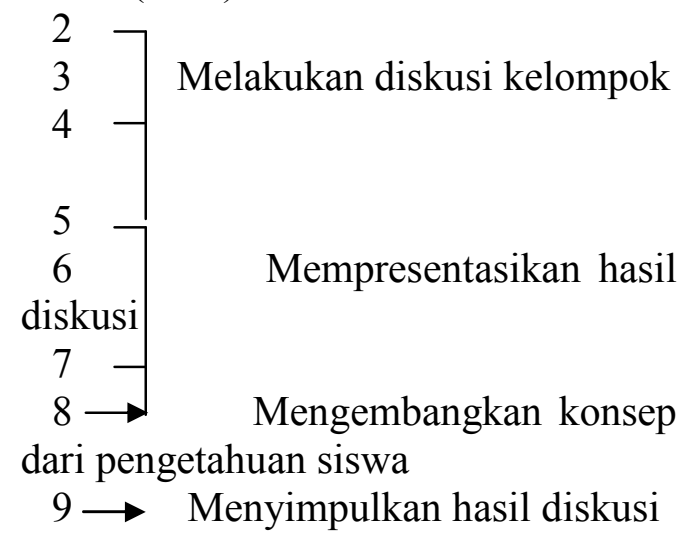

\section{b.Penjelasan kegiatan siswa}

Siswa A pada waktu 10 menit ke 1 keasikan membaca buku teks, waktu 10 menit ke-2 dan 3 siswa berbicara dengan kelompok lain, waktu 10 menit ke 8 tidak mengembangkan konsepnya,10 menit ke 9 siswa tidak menyimpulkan hasil.
Siswa B pada waktu 10menit ke 5, 6 dan 7 belum berani mempresentasikan hasil diskusinya, waktu 10 menit ke 8 dan 9 masih terlihat ragu dalam mengembang konsepnya serta tidak membuat kesimpulan karena waktu yang tidak cukupi.

Siswa C pada waktu 10 menit ke 2, 3 dan 4 tidak melakukan diskusi melainkan membawa buku, waktu 10 menit ke 8 tidak terlihat adanya pengembangan dari konsep yang dimilikinya, waktu menit 10 ke 9 siswa belum sempat menyimpulkan dikarenakan waktu tidak mencukupi.

Siswa D waktu 10 menit ke 1 belum siap untuk melakukan diskusi, waktu 10 menit ke 5, 6 dan 7 tidak melakukan diskusi melainkan berbicara dengan kelompok lain, waktu 10 ke 8 belum mengembangkan konsepsinya, waktu 10 menit ke 9 belum sempat membuat simpulan. 
Siswa E waktu 10 menit ke 2, 3 dan 4 bercanda dengan kelompok lain, waktu 10 menit ke 7 siswa belum leluasa mempesentasikan hasil diskusinya, waktu 10 menit ke 8 belum mengembangkan konsepnya, waktu 10 menit ke 9 belum sempat membuat simpulan karena waktu sudah habis.

Siswa F waktu 10 menit ke 1 berbicara dengan kelompok lain, waktu 10 menit ke 5, 6 dan 7 siswa lebih memilih menulis, waktu 10 menit ke 8 belum terlihat mengembangkan konsepnya, waktu 10 menit ke 9 siswa belum sempat membuat simpulan karena waktunya yang tidak memungkinkan.

Dari kegiatan prasiklus diketahui bahwa keterampilan siswa belum terlihat perkembangan yang berarti dari keenam siswa yang diobservasi.

Tabel 10. Hasil Observasi Kegiatan Siswa Siklus I

\begin{tabular}{ccccccccccc}
\hline & Kode & $10 ”$ & $10 ”$ & $10 ”$ & $10 ”$ & $10 ”$ & $10 ”$ & $10 ”$ & $10 ”$ & $10 ”$ \\
\hline No. & Siswa & 1 & 2 & 3 & 4 & 5 & 6 & 7 & 8 & 9 \\
\hline 1. & A & $\checkmark$ & $\checkmark$ & $\checkmark$ & $\checkmark$ & $\checkmark$ & $\checkmark$ & $\checkmark$ & $\checkmark$ & - \\
2. & B & - & $\checkmark$ & $\checkmark$ & $\checkmark$ & $\checkmark$ & $\checkmark$ & $\checkmark$ & - & - \\
3. & C & - & $\checkmark$ & $\checkmark$ & $\checkmark$ & $\checkmark$ & $\checkmark$ & $\checkmark$ & $\checkmark$ & - \\
4. & D & $\checkmark$ & $\checkmark$ & $\checkmark$ & - & $\checkmark$ & $\checkmark$ & $\checkmark$ & $\checkmark$ & - \\
5. & E & $\checkmark$ & - & $\checkmark$ & - & $\checkmark$ & - & $\checkmark$ & - & - \\
6. & F & $\checkmark$ & $\checkmark$ & $\checkmark$ & $\checkmark$ & - & - & $\checkmark$ & - & - \\
\hline
\end{tabular}

\section{a. Aspek yang diamati}

$1 \rightarrow \quad$ Mengamati Lembar Diskusi Siswa (LDS)

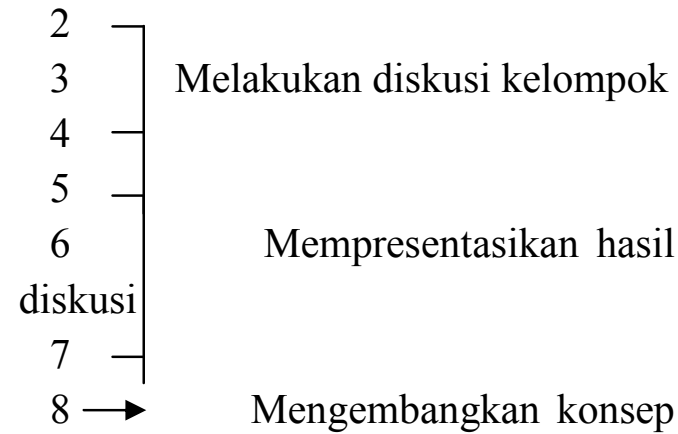
dari pengetahuan siswa

$9 \rightarrow$ Menyimpulkan hasil diskusi

\section{b. Penjelasan Kegiatan Siswa}

Siswa A pada waktu 10 menit ke 9 tidak sempat membuat kesimpulan hasil diskusi dikarenakan waktu yang sudah habis.
Siswa B pada waktu 10 menit ke 1 merasa kebingungan waktu mengamati LDS, waktu 10 menit ke 8 dan 9 masih

terlihat ragu dalam mengembang konsepnya serta tidak membuat kesimpulan karena waktu yang tidak cukupi.

Siswa C pada waktu 10 menit ke 1 memperhatikan anggota lain, waktu 10 menit ke 9 tidak sempat membuat kesimpulan karena waktu yang tidak mencukupi.

Siswa D waktu 10 menit ke 4 tidak melakukan diskusi melainkan berbicara dengan teman sekelompoknya (siswa E), waktu 10 menit ke 9 siswa tidak sempat membuat simpulan karena waktu yang tidak cukup.

Siswa E waktu 10 menit ke 2 dan 4 tidak memperhatikan temannya yang sedang diskusi melainkan menulis, waktu 10 menit ke 6 tidak memperhatikan waktu presentasi 
kelompok lain, waktu 10menit ke 8 dan 9 tidak mengembangkan konsepnya masih terlihat ragu dan tidak sempat membuat kesimpulan karena waktu yang tidak memungkainkan.
Siswa F waktu 10 menit ke 5 dan 6 tidak memperhatikan saat temannya presentasi, waktu 10 menit ke 8 dan 9 belum mengemukakan pendapatnya dan tidak menyimpulkan hasil diskusinya karena waktu yang tidak mencukupi.

Tabel 11. Hasil Observasi Kegiatan Siswa Siklus II

\begin{tabular}{ccccccccccc}
\hline & Kode & $10 "$ & $10 ”$ & $10 ”$ & $10 ”$ & $10 ”$ & $10 ”$ & $10 ”$ & $10 ”$ & $10 ”$ \\
\hline No. & Siswa & 1 & 2 & 3 & 4 & 5 & 6 & 7 & 8 & 9 \\
\hline 1 & A & $\checkmark$ & $\checkmark$ & $\checkmark$ & $\checkmark$ & - & - & $\checkmark$ & $\checkmark$ & $\checkmark$ \\
2 & B & $\checkmark$ & $\checkmark$ & $\checkmark$ & $\checkmark$ & - & - & $\checkmark$ & $\checkmark$ & $\checkmark$ \\
3 & C & $\checkmark$ & $\checkmark$ & $\checkmark$ & $\checkmark$ & - & $\checkmark$ & $\checkmark$ & - & $\checkmark$ \\
4 & D & $\checkmark$ & - & - & $\checkmark$ & $\checkmark$ & $\checkmark$ & $\checkmark$ & $\checkmark$ & $\checkmark$ \\
5 & E & $\checkmark$ & $\checkmark$ & $\checkmark$ & $\checkmark$ & $\checkmark$ & & $\checkmark$ & $\checkmark$ & $\checkmark$ \\
6 & F & $\checkmark$ & $\checkmark$ & - & - & $\checkmark$ & $\checkmark$ & $\checkmark$ & $\checkmark$ & $\checkmark$ \\
\hline
\end{tabular}

a. Aspek yang diamati

$1 \rightarrow \quad$ Mengamati Lembar Diskusi Siswa (LDS)

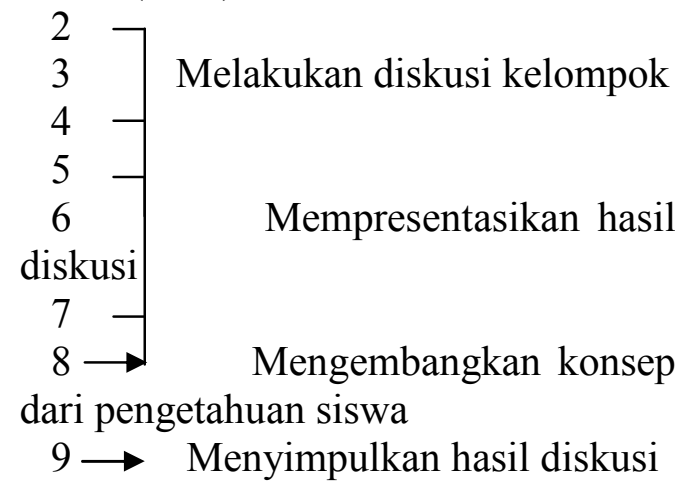

\section{b.Penjelasan kegiatan siswa}

Siswa A dan B pada waktu 10 menit ke 6 dan 7 lebih banyak membaca buku daripada memperhatikan siswa yang sedang presentasi.

Siswa C pada waktu 10 menit ke 5 lebih banyak mencatat daripada memperhatikan temannya yang sedang presentasi, waktu 10 menit ke 8 tidak mengembangkan konsepnya.

Siswa D pada waktu 10 menit ke 2 dan 3 lebih banyak membaca buku daripada diskusi dengan teman sekelompoknya.

Siswa E pada waktu 10 menit ke 6 lebih banyak membaca buku daripada memperhatikan teman yang sedang presentasi.

Siswa F waktu 10 menit ke 3 dan 4 tidak ikut terlibat diskusi kelompok melainkan membaca dan terdiam.

Tabel 12. Hasil Observasi Kegiatan Siswa Siklus III

\begin{tabular}{ccccccccccc}
\hline & Kode & $10 "$ & $10 "$ & $10 "$ & $10 "$ & $10 ”$ & $10 "$ & $10 ”$ & $10 "$ & $10 "$ \\
\hline No. & Siswa & 1 & 2 & 3 & 4 & 5 & 6 & 7 & 8 & 9 \\
\hline 1. & A & $\checkmark$ & $\checkmark$ & - & $\checkmark$ & $\checkmark$ & $\checkmark$ & - & $\checkmark$ & $\checkmark$ \\
2. & B & $\checkmark$ & $\checkmark$ & $\checkmark$ & $\checkmark$ & - & - & - & $\checkmark$ & $\checkmark$ \\
3. & C & $\checkmark$ & $\checkmark$ & $\checkmark$ & $\checkmark$ & - & $\checkmark$ & - & $\checkmark$ & $\checkmark$ \\
4. & D & $\checkmark$ & - & $\checkmark$ & $\checkmark$ & $\checkmark$ & $\checkmark$ & $\checkmark$ & $\checkmark$ & $\checkmark$ \\
5. & E & $\checkmark$ & - & $\checkmark$ & $\checkmark$ & $\checkmark$ & & $\checkmark$ & $\checkmark$ & $\checkmark$ \\
6. & F & $\checkmark$ & $\checkmark$ & - & & $\checkmark$ & $\checkmark$ & $\checkmark$ & - & $\checkmark$ \\
\hline
\end{tabular}


a. Aspek yang diamati

$1 \rightarrow \quad$ Mengamati Lembar Diskusi Siswa (LDS)

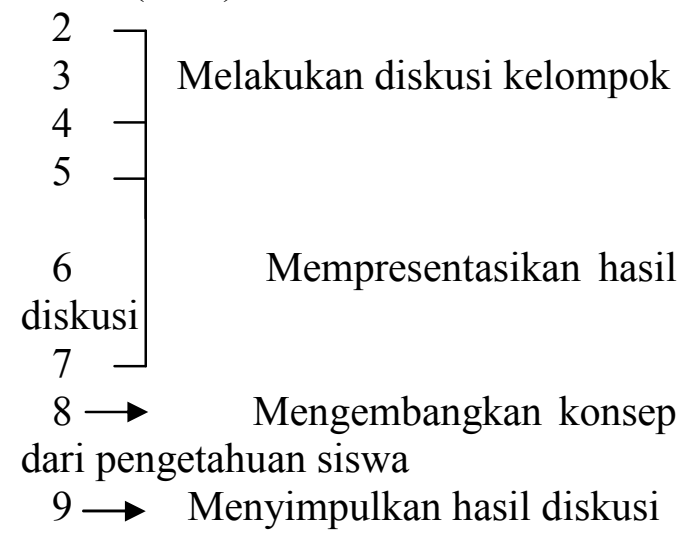

\section{b. Penjelasan kegiatan siswa}

Siswa A dan B pada waktu 10 ke 3 lebih banyak membaca buku, waktu 10 ke 7 tidak memperhatikan yang sedang presentasi.

Siswa B dan D pada waktu 10 menit ke 4 lebih banyak membaca daripada diskusi dengan teman sekelompoknya.

Siswa $F$ waktu 10 menit ke 5 dan 6 berbicara dengan anggota kelompok lain, pada waktu 10 menit ke 7 terlihat kelelahan tidak memperhatikan saat temanya presentasi, pada waktu 10 menit ke 8 tidak banyak mengemukakan pendapat.

\section{e. Observasi Kegiatan Guru}

Kegiatan Observasi bertujuan untuk melihat langsung peristiwa, kejadian dan prilaku guru pada saat kegiatan belajar mengajar berlangsung (Nana Sudjana, 1991:64), kegiatan observasi dilakukan dengan tujuan untuk mengumpulkan informasi tentang kegiatan guru selama proses pengajaran biologi dikelas. Dari data yang diperoleh melalui pembelajaran selama 3 siklus, guru mulai memecahkan permasalahannya sehingga siklus demi siklus pembelajaran sudah terasa efektif.

Hasilobservasi kegiatan guru saat pembelajaran pada siklus I guru masih terlihat kaku, masih banyak hal-hal yang belum dikembangkan.Keadaan ini terlihat dari waktu yang digunakan.Dari beberapa tahapan pembelajaran banyak waktu yang tidak sesuai dan guru masih belum menemukan pola yang tepat dari strategi yang digunakan.

Keadaan tersebut dipengaruhi oleh beberapa faktor salah satu diantaranya yaitu guru belum terbiasa dengan strategi pembelajaran yang digunakan.Oleh sebab itu observer berusaha mengetahui kendala yang dihadapinya melalui wawancara yang dilakukan setelah pembelajaran, dari informasi yang diperoleh guru berusaha seoptimal mungkin untuk membantu siswa dalam memahami konsep.Pada siklus II guru sudah bisa mengolah pembelajaran.

Hasil observasi siklus II menunjukan bahwa guru telah menunjukan usahanya selama pembelajaran.dari aktivitas guru selama pembelajaran pada siklus II. Guru mulai mengantisipasi beberapa faktor yang menghambat selama pembelajaran. Oleh karena itu proses pembelajaran berkembangan kearah yang lebih baik, tetapi mengenai waktu guru masih belum menemukan solusi yang tepat. Hal tersebut terlihat ketidak sesuaian waktu yang digunakan selama pembelajaran.Siswa masih merasa terburu-buru selama proses pembelajaran berlangsung.

Berdasarkan hasil observasi dari kedua siklus terakhir guru sudah dapat mengembangkan pembelajaranya. Guru sudah terlihat aktif dan antisifatif terhadap proses pembelajaran. Hal tersebut terlihat bahwa terpecahkannya masalah waktu mendorong pembelajaran menjadi lebih efektif.

\section{f. Catatan Lapangan}

Catatan lapangan digunakan sebagai data penunjang selama kegiatan dengan tujuan untuk mengetahui hal-hal apa yang menjadi permasalahan dalam proses penelitian, selain itu kegiatan tersebut bertujuan untuk mendeskripsikan berbagai 
aktivitas kegiatan guru selama proses pembelajaran berlangsung, segala bentuk aktivitas guru dicatat oleh observer dan dirumuskan sebagai salah satu rujukan dalam perbaikan untuk pembelajaran berikutnya. Mencatat keadaan yang terjadi dilapangan untuk mengetahui keadaan yang dianggap perlu untuk didiskusikan selama kegiatan pengajaran berlangsung yang tidak dapat direkam melalui observasi.

\section{g. Wawancara}

Wawancara merupakan kegiatan untuk memperoleh informasi. Sesuai tidaknya data diperoleh sangat dipengaruhi oleh beberapa aspek wawancara. Wawancara ini dimaksudkan untuk mengetahui pendapat, aspirasi harapan, dan keinginan siswa yang mendukung hasil belajar mereka. Wawancara dilaksanakan setelah pembelajaran berakhir. Adapun hasil wawancara yang diperoleh dapat dilihat dari tabel hasil wawancara.

Pada pertemuan ke-3 terjadi peningkatan dalam hal pengembangan kegiatan belajar siswa, hal tersebut terlihat pada tabel 1.12. Dari tabel tersebut siswa sudah ikut berpartisipasi dalam proses pembelajaran yaitu siswa diberi kesempatan secara bergantian untuk menjelasakan atau menanggapi hasil pengembangan pengetahuan dari masing-masing kelompok, dengan demikian dari setiap siswa sebagai perwakilan kelompok mendapatkan kesempatan untuk dapat mengembangkan pengetahuannya sehingga mereka menjadi terampil, hal tersebut terlihat saat presentasi selama proses belajar berlangsung. Dengan demikian memberikan kesempatan kepada siswa dalam melakukan suatu kegiatan belajar merupakan langkah tepat dalam pembelajaran pendekatan ekspositori.

Menurut Wina Sanjaya (2007: 188) Situasi demikian merupakan kadaan yang mendorong dimana untuk menghubungkan materi pelajaran dengan pengalaman siswa atau dengan hal-hal lain yang memungkinkan siswa dapat menagkap keterkaitannya dalam struktur pengetahuan yang telah dimilikinya, dengan demikian memberikan kesempatan kepada siswa yangsebanyak-banyaknya dalam pembelajaran lebih bermanfaat baginya karena mereka akan senantiasa berusaha membangun pengetahuan dan kemampuannya sendiri.

Adapun tanggapan guru tentang kegiatan pegajaran yang telah dikembangkan menunjukan bahwa guru memperlihatkan suatu usaha untuk memperbaiki kekurangan ataupun mengurangi hal-hal yang sekiranya akan menghambat terhadap proses berlangsungnya pembelajaran. Dengan adanya saran dan masukan, guru mulai memperhatikan hal tersebut, dengan tujuan supaya adanya peningkatan kualitas pembelajaran didalam kelas.

Siklus terakhir guru telah memecahkan rasa penasaran yaitu untuk kesesuaian waktu yang telah direncanakan. Dari cuplikan wawancara diatas membuktikan bahwa kesesuaian waktu dengan materi yang telah direncanakan mendorong siswa belajar menjadi lebih efektif.

\section{Simpulan dan Saran}

Berdasarkan hasil penelitian tentang peningkatan hasil belajar siswa pada sub materi pokok sistem reproduksi wanita dengan menggunakan pendekatan ekspositori dikelas XI pada salah satu sekolah SMAN 24 Kota Bandung.dapat disimpulkan bahwa:

1. Hasil belajar kognitif siswa berdasarkan pretes dengan nilai 31.9, sedangkan hasil belajar postes dengan nilai 59.6. Hasil penelitian menunjukkan terdapat peningkatan hasil belajar secarasignifikankarena $t_{\text {hitung }}=-10.392<$ 
$\mathrm{t}_{\text {daftar }}=2.656$, dengan rata-rata nilai gain sebesar 28 .

2. Sebagian besar siswa (52.12\%) setelah proses pembelajaran menunjukkan sikap senang terhadap pendekatan ekspositori,35.88\% siswa kurang menyukai terhadap pendekatan ekspositori dan $12.00 \%$ siswa tidak menyatakan sikap (ragu) terhadap pendekatanekspositori setelah pembelajaran berlangsung.

3. Keterampilan siswa selama proses pembelajaran berlangsung berkembang kearah positif. Hal tersebut terlihat pada keterampilan siswa pada siklus I sebesar $61.0 \%$, siklus II sebesar $80.0 \%$ dan keterampilan siswa pada siklus III sebesar $91.5 \%$.

4. Dari hasil belajar yang diperoleh terlihat adanya peningkatan hasil belajar siswa. Hal tersebut didukung dari hasil wawancara dan observasi selama pembelajaran berlangsung yang menunjukkan bahwa hasil belajar mereka berkembang kearah positif.

Daftar Pustaka

Abdorrahman Gintings,2008. Edisi Praktis: Belajar dan Pembelajaran. Humaniora: Jakarta.

Campbell, dkk 2004. Biologi Edisi 5- Jilid 3. Erlangga: Jakarta.

Cik Hasan Bisri, 2003.Penuntun Penyusunan Rencana Penelitian dan Penyesuaian Skripsi. Rajagrafindo Persada: Bandung.

Diah Aryuliana dkk.2007 Biologi 2untuk $S M A / M A$. Erlangga: Jakarta.

Eman Suherman dan Yaya Sukjaya. 1990 Petunjuk Praktis untukMelaksanakan Evalusai Pendidikan Matematika. Wijayakusumah: Bandung.

Endi Nugraha, 1985. Statistik unuk Penelitian. CV. Pramadi: Bandung.

Epi Parlina, 2004. Pemahaman Siswa Tentang Sub Konsep Protein
Hubungannya dengan Sikap Siswa Terhadap Model Pembelajaran Peta Kosep. Skripsi.Tidak Dipublikasikan. Igak Wardhani, 2004. Penelitian Tindakan Kelas. Universias Terbuka: Jakarta.

Irfan Maturidi, 2004. Peningkatan Hasil Belajar Siswa dengan Menggunakan Pendektan Ekspositori pada Sub Konsep Alat Indra Mata dan Telinga. Skripsi. Tidak Dipublikasikan.

Kunandar, 2008. Langkah Mudah Penelitian Tindakan Kelas Sebagai Pengembangan Profesi guru. Rajagrafindo Persada: Jakarta.

Kus Irianto, 2007. Struktur dan Fungsi Tubuh Manusia Paramedis. Yrama Widya: Bandung.

Lina Rahmawidiyati, 2006.Perbedaan Peningkatan Kognitif Siswa pada Materi Pokok Virus antara yang Menggunakan Ekspositori dengan Pendekatan Konvensional. Skripsi.Tidak Dipublikasikan.

Mohammad Ali dan Muhammad Asrori, 2004. Psikologi Remaja Perkembangan Peserta Didik. Bumi Aksara: Bandung.

Muhibbin Syah, 2004. Psikologi Pendidikan dengan Pendekatan Baru. Remaja Rosdakarya: Bandung.

Nana Sudjana, 1991. Teori-teori Belajar untuk Pengajaran. Lembaga Penerbit Fakultas Ekonomi Universitas Indonesia: Jakarta.

Nana Sudjana, 2005. Penilaian Hasil Proses Belajar Mengajar. Remaja Rosdakarya: Bandung.

Nuryani Rustaman, 2005.Strategi Belajar Mengajar Biologi. Universitas Negeri Malang. Malang.

Paul Suparno, 2007.Riset Tindakan untuk Pendidik. Grasindo: Jakarta.

Rochiati Wiraatmadja, 2007.Metode Penelitian Tindakan Kelas. Remaja Rosdakarya: Bandung. 
Robert E. Slavin. 2008.Cooperative Learning Teori. Riset dan Praktik. Nusa Media: Bandung.

Rahayu Dindardiya, 2007.Penggunaaan Pendekatan Keterampilan Proses Sains Pada Pembelajaran Molusca Untuk Meningkatkan Hasil Belajar Siswa. Skripsi. Tidak Dipublikasikan Slameto, 1988. Belajar dan Faktorfaktor yang Mempengaruhinya. Bumi Aksara: Jakarta.

Suharsimi Arikunto, 2005. Dasar-dasar Evaluasi Pendidikan.Bumi Aksara: Jakarta.

Suharsimi Arikunto dkk. 2005. Penelitian Tindakan Kelas.Bumi Aksara: Jakarta.

Susilo, 2007. Panduan Penelitian Tindakan Kelas.Pustaka Book Publiser: Yogyakarta.

Sobry Sutikno, 2004. Belajar dan Pembelajaran"Upaya Kreatif dalam Mewujudkan Pembelajaran yang berhasil.Prospect:Bandung.
Syaiful Bahri Djaramah dan Aswan Zain, 2002.Strategi Belajar Mengajar.Rineka Cipta: Jakarta.

Syaiful Sagala, 2005. Konsep dan Makna Pembelajaran.Alpabeta: Bandung.

Suwarno, 1982. Pengantar Umum Pendidikan.Aksara Baru: Surabaya.

Tabrani Rusyan, $1989 . \quad$ Pendekatan Dalam Proses Belajar Mengajar. Remaja Karya: Bandung.

Wina Sanjaya. 2005. Pembelajaran Berorientasi Standar Proses Pendidikan. Prenada Media. Jakarta.

Yatni Sugiatni, 2000.Peningkatan Hasil Belajar Siswa dalam Respirasi Anaerob dan Aerob dengan Menggunakan Pendekatan Sain Teknologi Masyarakat. Tesis. Tidak Dipublikasikan.

Zainal Aqibi, 2007.Penelitian Tindakan Kelas untuk Guru. Yrama Widiya:Bandung. 